\title{
Khasi traditional tree farming practice on pest and disease management in the Northeast uphill of Bangladesh
}

\author{
Nur Mohammad Majumder
}

Dept. of Anthropology, Shahjalal University of Science and Technology, Sylhet-3114, Bangladesh

$₫$ For any information: ask.author@journalbinet.com, Received: 24.06.17, Revised: 16.08.17;

Available online: 25 September 2017.

\begin{abstract}
Traditional cultivation system is an ecologically based age-old farming system, which is developed by native farmers through generations after generation. It is the resulting of their interaction with nature and natural resources for food, fuel, fodder and fibre. However, it is necessary to investigate how Khasi in northeast uphill take care and protect various tree crops from the nuisance of pest and diseases employing indigenous knowledge. This study also examined what kinds of knowledge, farming inputs with local pesticides, source and scale of materials are used to grow healthy tree crops in the field. To explore these farming issues a qualitative approach participant observation method with in-depth interviewing techniques were employed to elicit data in the field. Findings illustrated that traditional knowledge as local knowledge of the people has occupied in different topographical areas of the country with their surrounding natural setting specially, local culture, custom, belief, folklore, rites and rituals. This report is an attempt to document some empirical issues of the indigenous practices followed by local farmers for the organizational and managerial strategy of pests and diseases of certain common tree crops grown in traditional fields in general and north east Bangladesh in particular. This study identified various indigenous pest management practices, which have scientific basis of practicing them.
\end{abstract}

Key Words: Khasi, Agricultural farming, Indigenous knowledge, Pest and disease management and Ethnoecological knowledge

Cite Article: Majumder, N. M. (2017). Khasi traditional tree farming practice on pest and disease management system in the Northeast uphill of Bangladesh. Journal of Bioscience and Agriculture Research, 15(01), 1238-1245. Crossref: https://doi.org/10.18801/jbar.150117.152

Article distributed under terms of a Creative Common Attribution 4.0 International License.

\section{Introduction}

Khasi are one of the major ethnic communities of north east Bangladesh, depending on tree crop farming practices for their earnings and livelihood. Their local farming system is ethnoecological based without exploitation of over natural resources, which is their age-old farming system (Nath et al., 2003). It is developed by local farmers through generation after generation of their communication with nature and natural resources for food fuel, fodder, resin and shelter. It is a local method of farming tree crops using own dependence locally available materials withoutmassive external/global 
materials. Indigenous cultivation system, once was extensive all over the world is now almost eroded from the developed countries limited to some ethnic dominated areas of developing countries engaging more than half of tillable land (Thurston, 1992). Anywhere they are, the general aspect of indigenous cultivation is the existence of spatial and temporal heterogeneity frequently with mix plant age arrangement, intercropping, multi-cropping, host-pathogen interactions and practice of easy instruments to till and harvest the crop. In Bangladesh Khasi use indigenous farming systems due to the diversity of agro-ecological settings and occupied by them, which is being practiced as age-old farming system since generation in a location of particular conditions. It is a tribal farming method, which gets the local people nearer and respects their nature and environment (Emery, 1996).

Khasi's tree crop farming tools and techniques either unidentified or least understood. However, with the arrival of scientific farming, customary cultivation system in Bangladesh is widely confined to uphill areas where the peripheral regions green revolution could not affects local and indigenous farmers. The diseases and pests situation of tree crops in traditional farming system is usually similar as that of traditional cultivation but the extent of severity due to different pests may vary. The tree crop cultivation in general and pest with diseases management system in particular are different among the local farmers those are practicing indigenous cultivation systems based on their local situated practice of pest controlling knowledge. Khasi accumulated their prevalent pest and diseases distracting knowledge over generation, which is closer to nature and environment (Agrawal and Gibson, 1999). It helps to develop ecofriendly and locally adapted farming system.

Khasi indigenous tree crop cultivation system is compound and distinct of its own as the land use technique in this region is dominated by slash and rot out surface vegetation system for soil nutrients where management of tree crops with controlling pests and diseases are carried out by combining indigenous knowledge and traditional folk ecological knowledge of the local peoples. These types of knowledge have been accepted by global scientists are viewing keen interest in traditional farming because local farmers and their applied pests management techniques could cure the deficiencies of pest management in modern agrofarming (Berkes et al., 2000).

Khasi regions have always been eco-friendly due to their rich traditional practice and there have had prosperous biomass. The farming land is fertilized by organic manure, which derives from forest biomass and livestock. For controlling menacing diseases and pests in farming, farmers depend on indigenous methods for centuries. It is observed that all of these are not potential. However, those are effective for forested hill farmers are used very little, which could be used as indigenous pest management package in overall farming system to protect ecology and environment.

\section{Materials and Methods}

Study site: Khasi indigenous people reside mainly at the greater Sylhet Division in the North-eastern region and border of Bangladesh. The study was conducted among them. For the study purpose Kulaura and Rajnagar sub-districts were selected considering Khasis' uphill tree-crops farm field with forest surroundings. The area lies between latitude $24^{\circ} 01^{\prime}$ to $25^{\circ} 15^{\prime}$ north and longitude $91^{\circ} 05^{\prime}$ to 92015' east. The north-eastern part of Sylhet is a broad, level valley. Indian Khasi and Jaintias' hills to the north form a barrier the base of which builds the district border.The study area was situated in a remote place and far from the district town of Sylhet, surrounded by forest, hill-hillocks, a number of streams and rivers. The soil, including clayey and sandy loams of hilly ground is especially fertile. The climate of Sylhet district is warm and humid, mean maximum and mean minimum temperatures are $33{ }^{\circ} \mathrm{C}$ and $18^{\circ} \mathrm{C}$ respectively. Mean humidity is $80 \%$ and mean annual rainfall is $3800 \mathrm{~mm}$ (Ahasan et al., 2010). There were five punji (villages) under this study, namely Singuir Punji, Islachara Punji, AmchariPunji, Aynachara Punji and Indanagar Punji. The population of these villages (punji) is near about 1000 to 1100 . Preliminary the study investigated these villages and finally took two villages of them specially, SinguirPunji and AmchariPunji. The inhabitants' source of livelihood is forest, traditional hill-farming and tree-crop cultivation system.

Selected two main villages - Singuir Punji and Amchari Punji, were interesting site, because of having physical proximity, one is dominated by un-classed State forest and other one is controlled by a reserve forest of Forest Department. Villagers farming items that mean categories of trees, system, 
concept, geographical location and landscape with secondary natural forest are almost similar. However, for looking similarities and contrast in tree-crop farming system of indigenous knowledge about management of pests and diseases of trees are observed and due to this purpose both villages were selected.

Methodology: I gathered data for this study over a period of nine months from 2014 to 2016. I engaged over 120 village inhabitants in open-ended interviews administered in Bengali language. The study used a purposive/criterion sampling strategy considering the entire farming population, those engaged in upland tree crop farming, aged between 15 to 55 years. In some instances informants were selected through criterion and snowball sampling techniques. The criterion sampling technique was employed to recruit in in-depth interviewees those directly related to tree crop farming practices. The snowballing strategy is adopted to recognize the knowledgeable and potential key informants to tree gardeners in the community, who were interviewed asked for further names, and so on. In other ways they were selected with the help of community leaders to cover a broad spectrum of socioeconomic classes, ethnic religious groups, gender, and age group as well as formal and informal education, certain experience and material culture. In different cases, especially remarkable home gardens or field plantings were noticed and the owner then defined as an interviewee. Using a general interview guide that was openly changed as new situations and information arose; I discussed local tree cultivation technique how they control pest and diseases by using local farming pesticides and prevalent situated practice while walking through their farm fields for direct observations.

Interviews were open-ended nature, though not all topics were sheltered in all interviews, but each main topic was at least covered by a large adequate sample to be flexible to some form of analysis. While the concentration of the study surrounded by tree-cultivation practice, discussion often also turn to general to acute farming issues about trees health and diseases, which provided additional information of distracting or controlling of pests and diseases in the fields. I also took details information of diverse local farming pesticides, which is concurrently used in modern horticulture, agroforestry and so on. The native tree residues and various categories of medicinal plants' sap and other organic materials are used to control pests and diseases that were also recorded.

This study employed the combination of insider (emic) and outsider (etic) approaches to understand the inherent quality of data, because the way in which they were elicited and the method in which they were analyzed. The open-ended nature of interview questions permitted the informants to use their own phrasein describing their knowledge, and particular words and terms were often jotted down in order to protect emic nature and farming culture. But real generalization and conceptualization of these individual, insider views into a widespread system was in large part carried out later by myself from an etic perspective.

\section{Results and Discussion}

White bugs and insects compose is the main pest of tree crops and food crops in northeast Khasi uphill. Previously, their harm was stated from few areas only but over the year. It has estimated the position of a severe pest in the whole hilly region causing damage to upland food crops, a major hill crop to the amount of about $80 \%$ under rain-fed cultivation. Among the different types of grubs and beetles the Anomala, dimidiate, rutelinae have been the main species in Khasi uphill (Ahmed and Islam, 2000). White grubs destruction are heavy in uphill-slopes land, which is mostly rain-fed. For distracting and controlling it, the hill farmers of Khasi take the initiatives below.

\section{Spreading medicinal plant powder in the field}

Hill farmers spread a few medicinal plants' powders at tree root and on soil to distract and control pest and diseases. They use neem, dutra, biskatali and jawa trees' extracts and useful plant parts specially, leaves, leaves cake, stem, fruits, tender shoot, flower, seeds, rhizome and so on, by mixing with one another at a certain extent, which is experiential basis. Some pests and diseases preventive plants are used which is prevalent in surrounding setting with diverse landscape namely, Azadirechtsindica,Pongamiaglabra, Vitexnugundo, Lantana camara, Calatropis gigantean, Catharanusroseus, Daturametel, Andrographispaniculata and Lucusaspera. 


\section{Spreading of decomposed household debris/manure}

Farmers sometimes make a stockpile of un-decomposed household debris in the fields due to shortage of labour. Khasi farmers use to carry the manure from their household or animal sheds to the farm all over the year, especially during the unseason time. This is viewed that by the cultivators white insect's inflictions are more brutal surrounding these stockpiles. This reason Khasi optimally decompose these materials and also must be habituated to monitor white grub attack. Global scientist and agronomist are agreed that white grubs lay eggs in un-decomposed household stockpile of debris on which early stages of grubs and beetles feed (Mondal, 2010). While the household discards are decomposed then it is spread in the fields, which prevent various categories of grubs.

\section{Use of calcium carbonate and oilcake}

Farmers widely used limestone powder in the field by mixing grind mustard oil cake to increase soil nutrients as well as to eliminate soil toxicity. It also helps to remove and control root rot diseases of trees with various fungal diseases. They use it in the pits while plant any vegetative reproductive sapling in the field. Moreover, while Khasi use household decompose organic manure they keep it in sunlight one/two weeks with mixing lime and oilcake to kill the harmful insect and bugs. Figure 01 shows how Khasi mix lime and mustard oilcake powder with household manure/cow dungand then they use it in tree roots as trees growth, quality and landscape (Arnold and Dewees, 1997). Khasi also use separately lime powder and mustard oilcake powder to disinfect the land to plant and grow chilli and betel leaves in the field. It was reported by the farmers that after use of lime and oilcake white grubs are not observed generally.

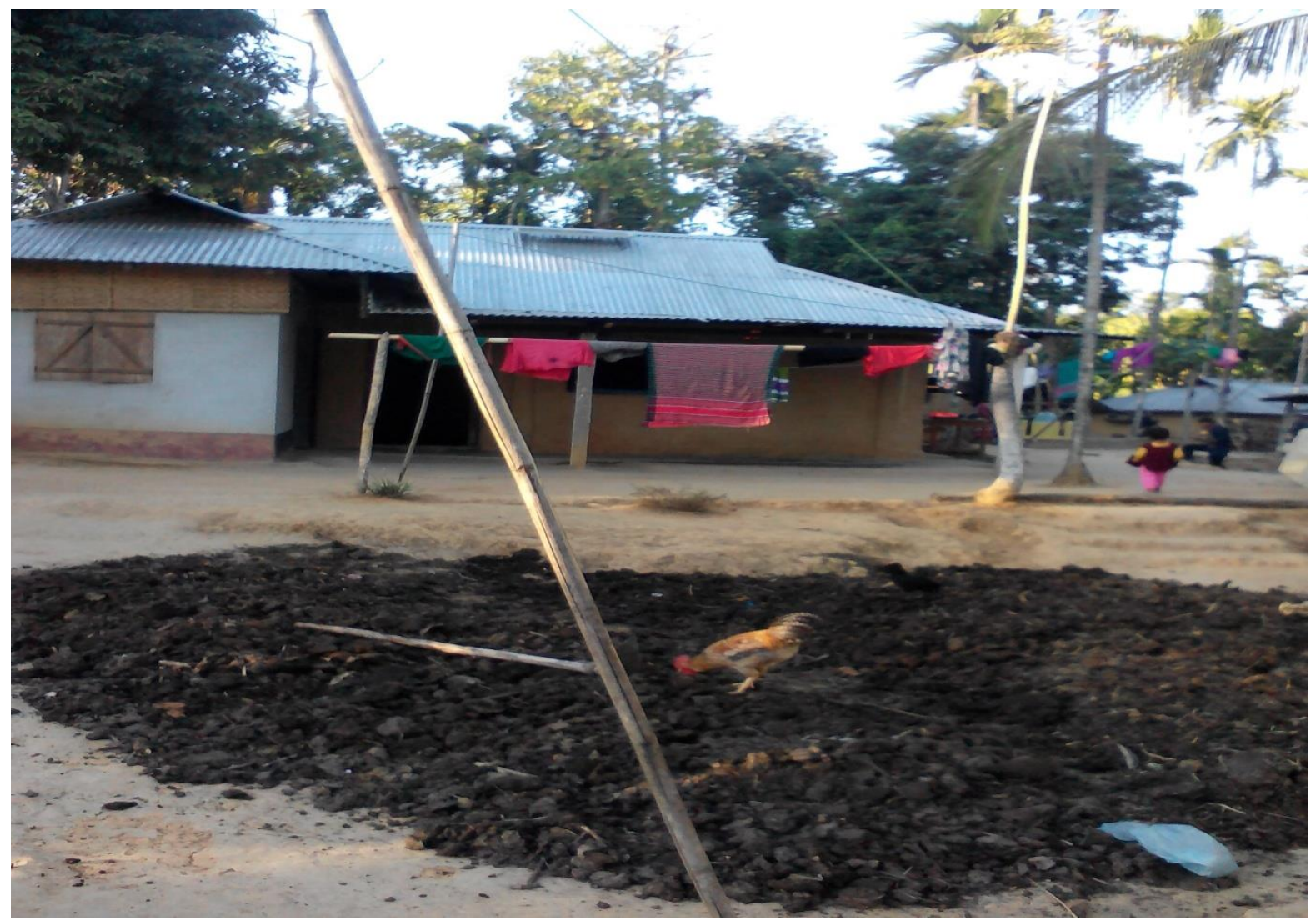

Figure 01. Field observation of preparing cow dung manure with mixed of limestone and oilcake powder.

\section{Fresh cow dung and cow urine}

This type of animal excreta is used by syringe to distract and control pests and diseases of trees. While this sort of disease and pest cuts tunnels from the roots upward to middle of stems, Khasi clean the inflicted twigs of surrounding trees. Later they use liquid fresh cow dung and cow urine like antibiotic to protect tree crops. Figure 02 shows the bored tree-stem of jackfruittree where liquid fresh cow dung and cow urine are used by syringe. The idea of fresh cow dung and cow urine was derived from 
hot concept which is used in folk concept Ayurveda health medicine (Brodt, 1999). The fresh cow dung is hot in nature and it can prevent the harmful microbes of tree diseases. If after using the fresh cow dung, medicinal plants' sap and cow urine and the diseases are not controlled, then a hotter (strong) chemical pesticide is mixed with it and used.

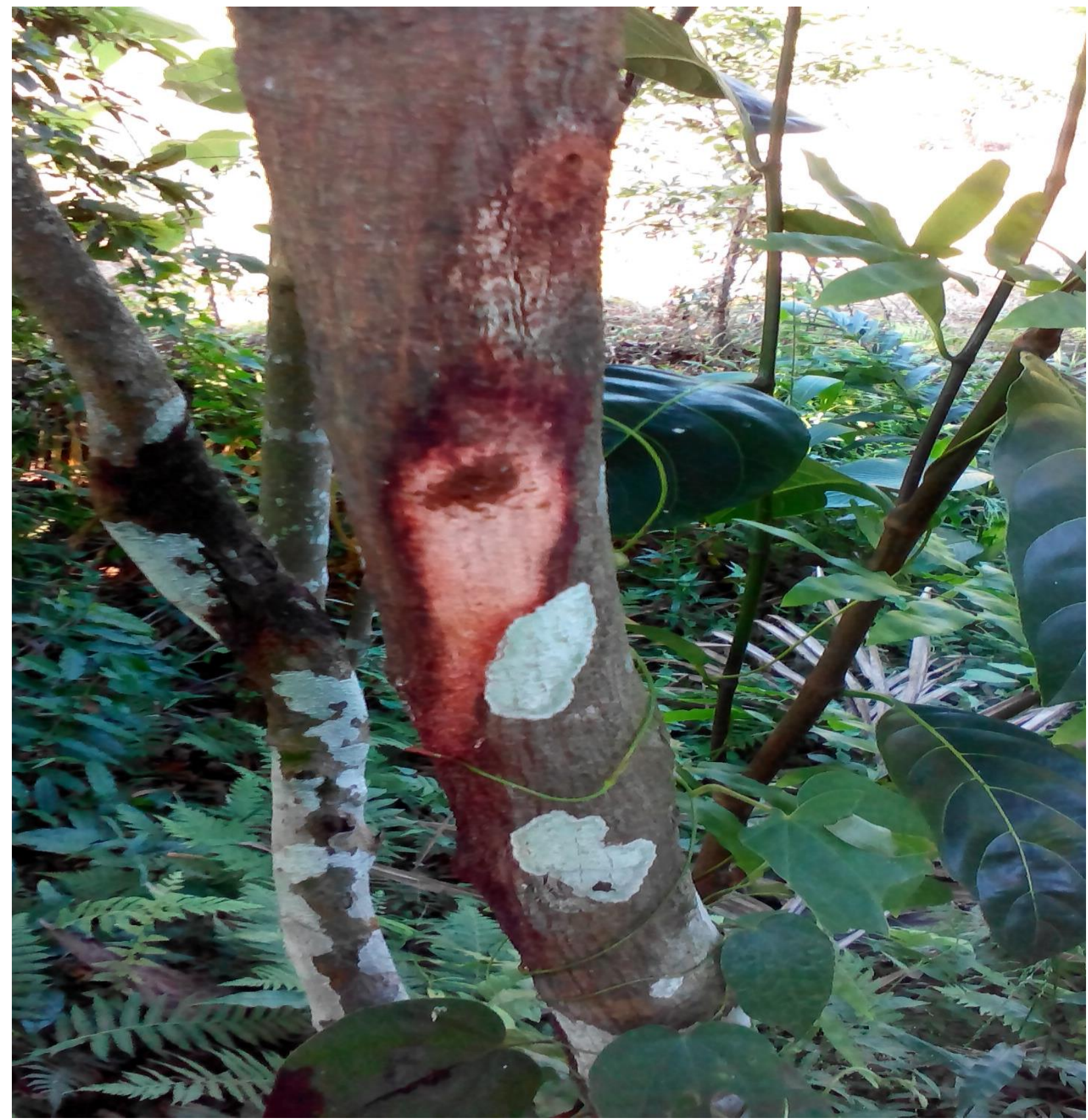

Figure 02. Field observation of disease infected bored jackfruit tree-stem.

\section{Use of table salt with sand}

For controlling white grub and various bugs, common salt with stone and bricks powder are put at pits earlier to plant seedling as trees structure and age. Sometimes farmers spread it in coconut and orange garden at the rate of $1 \mathrm{~kg} /$ Bigha. Bigha is an area of land to measure hill-plot. One bigha is equal to .03 acre. Farmers in upland use salt stone household at the same time for this purpose. Khasi thinly crush salt stone and combine it with sands or bricks powder to make it heavy. This mixture is scattered in the field or kept in the pits. Later wherever feasible, land is preferred to be watered. This practice is performed in the field where while grub destroys food and tree crops massively (Chandola et al., 2011). 


\section{Use of ash on standing crops}

Khasi normally do not use ashes in the uphill land pieces, because the outcome of it is setting fire, which could damage micro-organisms of soil. Conversely, torrential rain could wash away the ashes from the field. However, in dry season especially in vegetable field ashes are used by Khasi for protecting plants. In hilly regions, the kitchen ash, thus acquired is combined with the household manure or solely applied in the fields and onto plants. For insects it is very useful when having chewing and biting mouth parts. When bugs come to feed on ash spread-shoots its mouth is burned due to contact of ash carbon (Hakbijil, 2002). Ash also sticks to grubs mouth parts and spoils them because of which later insects are dead.

\section{Human icon and plastic sack hanging}

Human-emblems made from straw with wearing cloth are hanged in the field. Sometimes plastic sacks are also hanged around, which make sound through the air. The rodents and few mammals get afraid and run away without doing any harm to tree crops. This is a very age-old practice to protect harvest by using simple techniques. Now Khasi use metal bell with pendulum and ring it by pulling the rope from a specific safe place. The consequence of it rodents, bats and mammals run away.

\section{Rodent pests and mammals}

After various types of bugs and grubs, specially, rats, squirrels, monkeys and domestic pets are disturbing and harm on overall growth and protection of food and tree crops in the field. These pests eat and damage flower, fruits, stem and skin of trees and weaken the development of trees. As a group participant said that most of the trees, those trees' leaves and barks are sweet in taste to eat to pest, they like to eat and destroy them very much. In this case Khasi farmer sprinkle the liquid fresh cow dung on small tree shoots to restrain the domestic animal to eat the crops. However, it is a minor initiative of local people by adopting local knowledge to protect tree crops. Among various pest nuisances, rodents are the pests of agricultural produce at all stage; that is sapling, growth, harvesting and storage (Mohana and Rao, 1980). Rodents attack harshly and damage major standing crops, preserve food grains, afforestation trees, fodder crops and others necessary goods and they are the vital destructive vertebrate pests. Besides this pest, it carries major germs and diseases from place to place and tree to trees (WHO, 1974). Monkeys and squirrels also do the similar problems in spreading diseases. Khasi put various efforts to control these harmful rodent pests for over the years through local and chemical pesticides with various other methods. The hill farmers Khasi have used various methods for controlling them are illustrated below:

\section{Baiting}

Baiting is prepared by mixing $1 \mathrm{~kg}$ wheat flour, $1 / 2 \mathrm{~kg}$ dutra seed (poisonous) powder and $1 / 4 \mathrm{~kg}$ dry fish powder with little water. Then farmers make grand size pill from the mixture. The pills are kept closer to possible hole of rodent in the field at night. This is the popular method among the farmers for killing the rodents (Parshad, 1999). This kind of practice has observed widely in uphill farmers.

\section{Urea}

Seed shape of chemical fertilizer such as urea and other inputs Khasi use to distract rodents from the field. Urea is accumulated with other materials similar to a ball then put it at the entrance of mouse hole. However, global scientists were not confident about why they use it but Khasi said that urea discharge ammonia gas which could distract and often kill rodents (Subiah and Mathur, 1985).

\section{Faeces powdered of poultry}

The faeces powdered of poultry are kept at the opening of mouse hole. Because of its stink, rodents are made to run away that spot. Scientists did not assume it as a reasonable practice. A similar type of practice is also stated that cultivators were using the excreta of cats and dogs to isolate rodent out of the fields (Parshad, 1999). 


\section{Practice of local beliefs and customs}

Generally, all Khasi in term of religion and ethnicity agreed purity and pollution concepts, which is strictly adhered to tree conservation as well as pest and diseases management thoughts (Talang, 2013). They believe that if they maintain physical purity including their use of materials and utensils, trees will be safe from the menace of diseases and insects. This is the reason Khasi bathe before going to their farms. They think that all the evil with germs will be washed away and their garden will be free from pests and diseases. Whenever a diseased twig touches their bodies, they take a quick bath so that the diseases do not spread out. If massive amounts of diseased twigs are observed, they bury them in a specific corner of the farm field. Figure 03 illustrates the burial place of contagious diseases twigs where Khasi accumulate severely inflicted tree shoots to protect other trees.

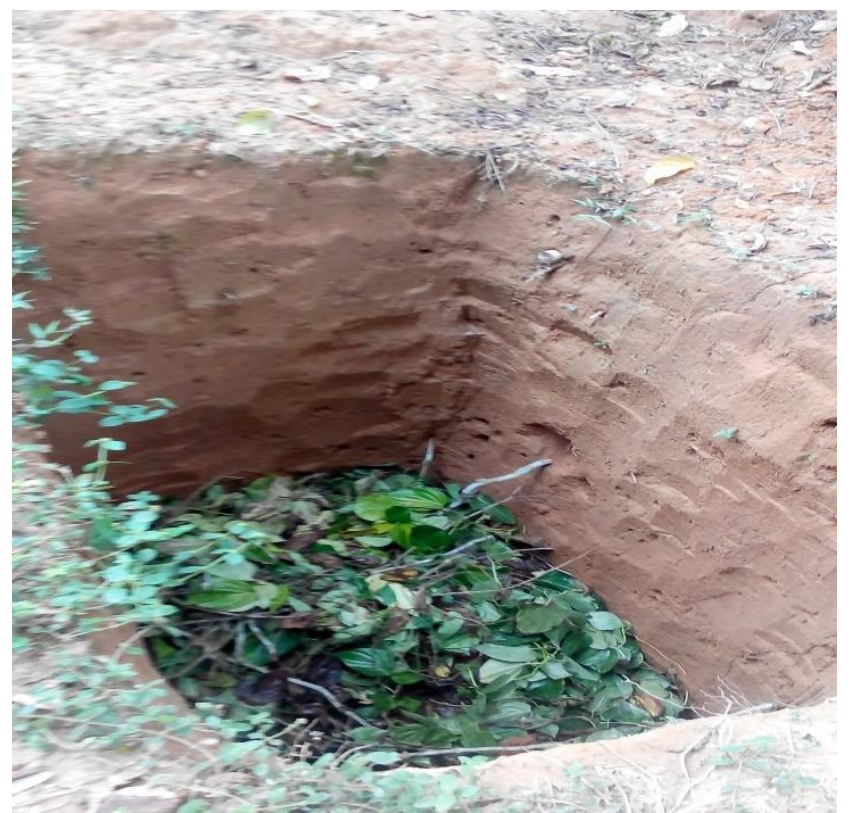

Figure 03. Filed observation of Pit of disease inflicted tree shoots and stems accumulation hole.

\section{Conclusion}

All together considering the local atmosphere and the fragile nature of uphill, the utilization of indigenous knowledge is of paramount importance. Where the major lowlanders of Khasi neighbour use huge quantity of chemical pesticides, fortunately uphill Khasi have not been popular yet and now farmers rely on traditional methods of pest and disease management. This is a chance to understand the positive impacts of local pest and disease management methods. This management method isintegrated by using local and modern farming inputs and pesticides optimallyand used locally with ecofriendly. Therefore, it is time to popularize integrated pest and diseases management method adopting location specific cheap practices.To perform this system, scientific examination and combination of effective local pest management practices with fresh science of indigenous pest management is essential.The extension of this era, produced fruits and tree crop organically from Khasi landscape can play a role to fulfil the global need of organic crops and poor as well as marginal peasants will be benefited.

\section{References}

[1]. Ahasan, M., Chowdhary, M. A. and Quadir, D. (2010). Variability and trends of summer monsoon rainfall over Bangladesh. Journal of Hydrology and Meteorology, 7 (1), 1-17.

[2]. Ahmed, M. and Islam, M. (2000). Efficacy of some fungicides and plant extracts against Bipolarisoryzae. MS Thesis, Department of Plant Pathology, Bangladesh Agricultural University, Mymensingh.

[3]. Arnold, J. M. and Dewees, P. A. (1997). Farms, trees and farmers: responses to agricultural intensification. London: Earthscan Publications.

[4]. Agrawal, A. and Gibson, C. C. (1999). Common property institutions and sustainable governance of resources. World development, 27 (4), 629-649. 
[5]. Berkes, F., Colding, J. and Folke, C. (2000). Rediscovery of traditional ecological knowledge as adaptive management. Ecological applications, 10(5), 1251-1262.

https://doi.org/10.1890/1051-0761(2000)010[1251:ROTEKA]2.0.CO;2

[6]. Brodt, S. B. (1999). Interactions of formal and informal knowledge systems in village-based tree management in central India. Agriculture and Human Values, 16(4), 355-363. https://doi.org/10.1023/A:1007537809389

[7]. Chandola, M., Rathore, S. and Kumar, B. (2011). Indigenous pest management practices prevalent among hill farmers of Uttarakhand.

[8]. Emery, A. R. (1996). The participation of indigenous peoples and their knowledge in Environmental Assessment and Development Planning (draft). Retrieved from Ottawa, Canada:

[9]. Hakbijl, T. (2002). The traditional, historical and prehistoric use of ashes as an insecticide, with an experimental study on the insecticidal efficacy of washed ash. Environmental Archaeology, 7(1), 13-22. https://doi.org/10.1179/env.2002.7.1.13

[10]. Mohana and Rao, A. M. K. (1980). Indian field mouse-a serious rodent pest of agriculture and its control. Pestology, 10 (6) 26-29.

[11]. Mondal, M. H. (2010). Crop agriculture of Bangladesh: challenges an opportunities. Bangladesh Journal of Agricultural Research, 35(2), 235-245.

https://doi.org/10.3329/bjar.v35i2.5886

[12]. Nath, T., Makoto, I., Islam, M. and Kabir, M. (2003). The Khasia tribe of northeastern Bangladesh: their socio-economic status, hill farming practices and impacts on forest conservation. Forests, Trees and Livelihoods, 13(4), 297-311.

https://doi.org/10.1080/14728028.2003.9752467

[13]. Parshad, V. R. (1999). Rodent control in India. Integrated Pest Management Reviews, 4(2), 97126. https://doi.org/10.1023/A:1009622109901

[14]. Subiah, K. S. and Mathur, R. P. (1985). Status of new rodenticides in India. PesBlogy. 9, 30-36.

[15]. Talang, F. B. (2013). The role of khasi in consevation of biodiversity and environment. Ecology and Environment, 10(4), 198-202.

[16]. Thurston, H. D. (1992). Sustainable practices for plant disease management in traditional farming systems: Westview Press, Inc.

[17]. WHO (1974). Anonymous, ecology and control of rodents of public health importance. Technical Report Series, 3 (1-42).

\section{HOW TO CITE THIS ARTICLE?}

\section{Crossref: https://doi.org/10.18801/jbar.150117.152}

\section{APA (American Psychological Association)}

Majumder, N. M. (2017). Khasi traditional tree farming practice on pest and disease management system in the Northeast uphill of Bangladesh. Journal of Bioscience and Agriculture Research, 15(01), 1238-1245.

\section{MLA (Modern Language Association)}

Majumder, N. M. "Khasi traditional tree farming practice on pest and disease management system in the Northeast uphill of Bangladesh". Journal of Bioscience and Agriculture Research, 15.01(2017): 1238-1245.

\section{Chicago and or Turabian}

Majumder, N. M. "Khasi traditional tree farming practice on pest and disease management system in the Northeast uphill of Bangladesh". Journal of Bioscience and Agriculture Research,15 no.01 (2017): 1238-1245. 